\title{
Live weight, carcass, and meat evaluation of Nellore, Curraleiro Pé-Duro, and their crossbred products in Piauí State
}

\author{
Geraldo Magela Côrtes Carvalho ${ }^{1 *}$, Marcílio Nilton Lopes da Frota ${ }^{1}$, Anisio Ferreira Lima Neto1, \\ Danielle Maria Machado Ribeiro Azevêdo ${ }^{1}$, Raimundo Bezerra de Araujo Neto ${ }^{1}$, Adriana Mello \\ de Araujo1, Elzânia Sales Pereira², Maria Socorro de Souza Carneiro²
}

\footnotetext{
${ }^{1}$ Empresa Brasileira de Pesquisa Agropecuária, Embrapa Meio-Norte, Teresina, PI, Brazil.

${ }^{2}$ Universidade Federal do Ceará, Departamento de Zootecnia, Fortaleza, CE, Brazil.
}

\begin{abstract}
The objective of this study was to evaluate live weight and carcass traits, from birth to slaughter, and meat quality of Nellore (NEL), Curraleiro Pé-Duro (CPD), and crossbred (F1) products in the state of Piauí, Brazil. Progenies from CPD, NEL, and their F1 crossbred ( $1 / 2$ NEL $+1 / 2$ CPD), a total of 252 , males and females, from birth to 24 months of age, were evaluated in a comparative study in growth performance. The steers were sent to slaughter at 28 months of age and carcasses and meat quality were analyzed. After slaughter, carcass weight, dressing percentage and Longissimus dorsi area (rib eye area) were evaluated; an index was created by the relationship between these measures per hundred $\mathrm{kg}$ of chilled carcass produced. To assess meat quality, the shear force, water-holding capacity, color, brightness, $\mathrm{pH}$, and cooking loss were investigated. Results obtained showed that month and year of birth were significant on growth, indicating influence of climatic variables. Nellore offspring was heavier than $\mathrm{F}_{1}$ and this was heavier than CPD throughout the study period, including the hot and cold carcass. No differences were found in dressing percentage among NEL and $\mathrm{F}_{1}$, but CPD and $\mathrm{F}_{1}$ showed a rib eye area and index significantly higher than NEL. The meat from CPD group presented a stronger red coloration than the others, but there was no significant difference in the remaining meat qualitative variables among the three groups. Curraleiro Pé-Duro and $\mathrm{F}_{1}$ crossbred produce more meat per $100 \mathrm{~kg}$ of carcass than Nellore in natural pasture of Piauí State.
\end{abstract}

Key Words: beef cattle, crossbreeding, heterosis, meat quality, local breeds, tropically adapted

\section{Introduction}

The Brazilian cattle herd is the largest commercial herd in the world with over 212,3 million heads (IBGE, 2014). It consists mainly of zebu breeds, being Nellore (B. indicus; NEL) and its crossbreeds around $80 \%$ of the National herd. The activity is established mainly in tropical regions and in low-quality pastures, which requires adapted genotypes for these places. According to Hammack (2012), specialty or local breeds should be used where their particular combinations of unusual traits are needed.

According to Athanassof (1946), a local breed of cattle named Curraleiro in some states, such as Goiás

Received: August 22, 2016

Accepted: January 30, 2017

*Corresponding author: geraldo.carvalho@embrapa.br

http://dx.doi.org/10.1590/S1806-92902017000500004

How to cite: Carvalho, G. M. C.; Frota, M. N. L.; Lima Neto, A. F.; Azevêdo, D. M. M. R.; Araujo Neto, R. B.; Araujo, A. M.; Pereira, E. S. and Carneiro, M. S. S. 2017. Live weight, carcass, and meat evaluation of Nellore, Curraleiro Pé-Duro, and their crossbred products in Piauí State. Revista Brasileira de Zootecnia 46(5):393-399

Copyright (C) 2017 Sociedade Brasileira de Zootecnia. This is an Open Access article distributed under the terms of the Creative Commons Attribution License (http://creativecommons.org/licenses/by/4.0/), which permits unrestricted use, distribution, and reproduction in any medium, provided the original work is properly cited. and Tocantins, and Pé-Duro in others, such as Piauí and Maranhão, is a well-adapted bovine that has not yet been improved; it is originated from bovines introduced in Brazil by the Portuguese and Spaniards during the colonization period. The Curraleiro breed stems from Bos taurus ibericus and, given its European origin, it is assumed to belong to the Bos taurus taurus subspecies (Britto and Mello, 1999). According to Cardoso et al. (2016), Curraleiro Pé-Duro breed had the lowest surface temperatures regardless of the period evaluated, with fewer animals that suffered with climatic conditions; so, this may be considered the best adapted when heat-challenged under experimental conditions compared with Nellore and Pantaneiro cattle.

The use of tropically adapted Taurine in crossbreeding could be an alternative to give use to local genetic resources to improve production and quality of meat in tropical and subtropical regions. Blackburn and Gollin (2009) highlighted that successful introduction of new breeds into the USA market has been based on several production traits and interest and acceptance of the private sector.

Some authors who have studied the products of crossbreeding among Taurine, tropically adapted Taurine, and Zebu cattle reported greater weight gain and increased meat production in a shorter time than 
in purebreds (Chase et al., 2000; Bonilla et al., 2007; Coleman et al., 2012; Sollecito et al., 2016). However, there is a lack of studies and information regarding the use of local breeds in industrial crosses, with the exception of Caracu breed that has already been evaluated in several production systems and diverse environments and is already part of Brazilian agribusiness (Bonilha et al., 2007; Moreira et al., 2016). Thus, this research aimed to evaluate the use of Curraleiro Pé-Duro (CPD) bulls in crossbreeding with Nellore (NEL) cows to increase meat production on natural pastures of Piauí State, Brazil, and to give use to this breed in risk of extinction.

\section{Material and Methods}

Data were collected from cattle herds in Piauí State, located in Mid North region of the Northeast of Brazil. Local climate is tropical with an irregular rainy season in summer from December to March and precipitation is around $800 \mathrm{~mm}$, without rain in the rest of the year (April to November). The predominant source of nutrition comes from seasonal growth of native pastures naturally enriched with leaves and pods from leguminous trees and bushes. Curraleiro Pé-Duro cattle used in this research came from an in situ conservation herd closed since 1985. Nellore breed is selected and registered as a "top" herd controlled by the Associação Brasileira dos Criadores de Zebu, both kept in an extensive system of pastures with fresh water and mineral supplementation and effective prevention and treatment of diseases and parasites.

Forty-five NEL cows were artificially inseminated with Nellore semen purchased in a local market to produce pure NEL calves; forty-five NEL cows were naturally bred by CPD bull to produce $\mathrm{F}_{1}$ calves, and forty-five CPD cows were naturally bred with CPD bulls to produce pure CPD calves from 2008 through 2010 to generate offspring in 2009, 2010, and 2011, respectively. Breeding season began on March 1 of each year and had 120 days in length. In each studied years, culled cows were replaced by others of the same genotype before the breeding period. Cows were replaced or culled only because of reproductive failure or death.

A total of 252 calves were born from January to April across the years $(2009,2010$, and 2011) (Table 1). At birth, all calves were ear-tagged, tattooed, and weighed (BW). They were weaned (210W) with an average of 210 days of life. During the pre-weaning period, calves were nursed by their dams with no food supplementation (concentrates). Calves were separated from cows at weaning, classified, and separated by sex and extensively grazed on native pastures until next rainy season, with mineral salt and water supplementation. Female calves, heifers, and cows were kept on better pastures with food supplementation during the dry period. After weaning, offspring were weighed at yearling (365W), 18 (18W), and 24 months (24W). Animals were fasted for $16 \mathrm{~h}$ before weighing. Other growth traits analyzed included average daily weight gain (ADG), from birth to $24 \mathrm{~W}$, and live weight before slaughter in steers at 28 months of age (SW). The period between $24 \mathrm{~W}$ and SW was 132 days and during this time, young bulls were placed on a pasture with higher protein and digestibility than the preceding time. After 24 months of age, females were sent for reproduction.

Animals were slaughtered in a commercial facility following the guidelines proposed by the Brazilian legislation according to technical regulation of stunning methods to humanitarian slaughtering of butcher animals (IN no. 3, of January 17, 2000). Live weight (SW) was assessed on the day of slaughter and immediately after slaughter, hot carcass (HC) was identified, weighed, and stored in a cooling chamber at approximately $2{ }^{\circ} \mathrm{C}$ for $24 \mathrm{~h}$ and then the weight of chilled carcass (CC) was achieved. Dressing (DRE) was achieved as the percentage of the live animal that ends up as carcass $((\mathrm{HC} \div$ live weight $) \times 100 \%)$. To access rib eye area (REA) measurement, an outline of the muscle was traced in vegetable paper and posteriorly expressed as the total area $\left(\mathrm{cm}^{2}\right)$ with the aid of a planimeter. To compare meat production of different carcass sizes that came from different genetic groups, it was necessary to convert them into a common carcass index achieved by the relationship between dressing percentage, rib eye area, and chilled carcass weight (INDEX). This was accomplished by the equation: $(\mathrm{DRE} \times \mathrm{REA}) / \mathrm{CC}$.

A sample from $L$. dorsi muscle between the 10th and 12th ribs was removed, packed, identified, cut in two steaks with approximately $2.5 \mathrm{~cm}$, frozen, and transported to evaluate meat quality. Meat traits were shear force, holding water capacity, meat luminosity, intensity of red color in meat, intensity of yellow color in meat, $\mathrm{pH}$, and cooking loss. Frozen steaks were thawed at $5{ }^{\circ} \mathrm{C}$ for $24 \mathrm{~h}$ and then

Table 1 - Experimental data analyzed by breeding group and years of birth of Nellore, Curraleiro Pé-Duro, and $\mathrm{F}_{1}$ crossbred progenies

\begin{tabular}{|c|c|c|c|c|c|c|c|}
\hline \multirow{2}{*}{$\frac{\text { Year }}{\text { Breed/Sex }}$} & \multicolumn{2}{|c|}{2009} & \multicolumn{2}{|c|}{2010} & \multicolumn{2}{|c|}{2011} & \multirow{2}{*}{ Total } \\
\hline & Male & Female & Male & Female & Male & Female & \\
\hline Nellore & 7 & 7 & 7 & 7 & 7 & 9 & 44 \\
\hline Curraleiro Pé-Duro & o 22 & 19 & 15 & 18 & 13 & 12 & 99 \\
\hline$F_{1}$ crossbred & 22 & 17 & 14 & 18 & 24 & 14 & 109 \\
\hline Total & 51 & 43 & 36 & 43 & 44 & 35 & 252 \\
\hline
\end{tabular}

R. Bras. Zootec., 46(5):393-399, 2017 
cooked on a conveyorized belt grill to a final internal temperature of $71{ }^{\circ} \mathrm{C}$ and Warner-Bratzler shear force was evaluated as described by Wheeler et al. (1998).

Data records were analyzed by least-square method using the general linear models procedure (Proc GLM) of SAS package (Statistical Analysis System, version 9.4). The model for growth performance included breed, calf sex, year of birth effects, and interaction between month and year of birth at $210 \mathrm{~W}, 365 \mathrm{~W}, 18 \mathrm{~W}$, and $24 \mathrm{~W}$. For weaning and post-weaning traits, age of calf was included in the model as a covariate. For carcass traits, the model used included breed effects, weight at slaughter, and age at slaughter as a covariate. Sex effects showed to be not significant and were deleted from the model. Carcass and meat quality were analyzed by SAS procedures in a model that encloses breeds and effects of slaughter weight and age of steers were used in the statistical model as covariate. Least square means and Tukey test values were used to estimate significant effect differences between means. Individual heterosis levels expressed in percentage was computed using linear contrasts between least squares means performance of crossbred animals $\left(\mathrm{F}_{1}\right)$ and average performance of NEL and CPD offspring.

This research was conducted in accordance with applicable federal, state, and local laws, regulations, and policies governing the care and use of animals and all procedures were performed in compliance with relevant laws and institutional guidelines. Slaughter was carried out in a packing house and followed all recommendations of the Ministério da Agricultura, Pecuária e Abastecimento (MAPA).

\section{Results}

There was no significant difference between sexes, although there was a tendency for females to be heavier than males at $24 \mathrm{~W}$. Breed had significant effects on all weights, in which Nellore products were heavier than $F_{1}$ and these heavier than CPD (Table 2).

Nellore group presented higher ADG and heavier SW, hot carcass, and chilled carcass, followed closely by $\mathrm{F}_{1}$. It was also observed great levels of heterosis on $F_{1}$ progeny (Table 3).

No significant level of heterosis was found for meat traits except for meat color (3.8\%).

Nellore offspring was heavier than $\mathrm{F}_{1}$ and this heavier than CPD throughout the study period, including hot and cold carcass. No differences were found in dressing percentage between Nelore and $F_{1}$, but CPD and $F_{1}$ showed significantly higher REA and INDEX than NEL. Meat from CPD group presented a pronounced red coloration compared with the other groups, but there was no significant difference in remaining qualitative variables among groups.

With respect to variables related to body size, there was a wide variation in minimum and maximum values due to differences among and within breeds (Table 4).

The levels of correlations between weights at different ages, medium to high, showed that selection for one trait may lead to changes in others (Table 5).

Table 2 - Analysis of variance of the environmental effects on weights of Nellore, Curraleiro Pé-Duro, and $F_{1}$ crossbred progenies analyzed

\begin{tabular}{lcccccc}
\hline Trait & BW & $210 \mathrm{~W}$ & $365 \mathrm{~W}$ & $18 \mathrm{~W}$ & $24 \mathrm{~W}$ & SW \\
\hline Sex of calves & $\mathrm{NS}$ & $\mathrm{NS}$ & $\mathrm{NS}$ & $\mathrm{NS}$ & $\mathrm{NS}$ & - \\
Breed of calves & $* *$ & $* *$ & $* *$ & $* *$ & $* *$ & $* *$ \\
Month of birth & $* *$ & $*$ & $* *$ & $\mathrm{NS}$ & $\mathrm{NS}$ & $\mathrm{NS}$ \\
Year of birth & $\mathrm{NS}$ & $* *$ & $* *$ & $*$ & $* *$ & - \\
Month $\times$ year of birth & $\mathrm{NS}$ & $*$ & $* *$ & $\mathrm{NS}$ & $\mathrm{NS}$ & $\mathrm{NS}$ \\
Age in days at weights & - & $* *$ & $* *$ & $*$ & $\mathrm{NS}$ & $\mathrm{NS}$ \\
\hline
\end{tabular}

BW - weight at birth; $210 \mathrm{~W}$ - weight at weaning at 210 days of age; $365 \mathrm{~W}$ - weight at yearling at 365 days of age; $18 \mathrm{~W}$ - weight at 18 months of age; $24 \mathrm{~W}$ - weight at 24 months of age; SW - weight at 28 months of age in the day of slaughter; NS - not significant.

$* \mathrm{P}<0.05$.

$* * \mathrm{P}<0.01$

Table 3 - Least square means for growth, carcass, and meat traits and individual heterosis for Nellore, Curraleiro Pé-Duro (CPD), and $\mathrm{F}_{1}$ crossbred progenies

\begin{tabular}{lcccc}
\hline Trait/Breed & Nellore & CPD & $\begin{array}{c}\mathrm{F}_{1} \\
\text { crossbred }\end{array}$ & $\begin{array}{c}\text { Heterosis } \\
(\%)\end{array}$ \\
\hline Birth weight & $30.43 \mathrm{a}$ & $20.16 \mathrm{c}$ & $28.81 \mathrm{~b}$ & 12.20 \\
Weaning weight & $147.57 \mathrm{a}$ & $66.53 \mathrm{c}$ & $128.46 \mathrm{~b}$ & 16.67 \\
Yearling weight & $182.20 \mathrm{a}$ & $95.54 \mathrm{c}$ & $175.48 \mathrm{~b}$ & 20.86 \\
Weight at 18 months & $210.09 \mathrm{a}$ & $131.95 \mathrm{c}$ & $202.62 \mathrm{~b}$ & 15.60 \\
Weight at 24 month & $266.30 \mathrm{a}$ & $160.47 \mathrm{c}$ & $255.62 \mathrm{~b}$ & 16.52 \\
Slaughter weight & $330.42 \mathrm{a}$ & $220.60 \mathrm{c}$ & $297.21 \mathrm{~b}$ & \\
Adjusted daily gain & $0.323 \mathrm{a}$ & $0.234 \mathrm{c}$ & $0.318 \mathrm{~b}$ & \\
Hot carcass weight & $155.92 \mathrm{a}$ & $93.20 \mathrm{c}$ & $141.42 \mathrm{~b}$ & \\
Chilled carcass weight (CC) & $152.83 \mathrm{a}$ & $91.08 \mathrm{c}$ & $138.33 \mathrm{~b}$ & \\
Dressing percentage (DRE) & $48.94 \mathrm{a}$ & $44.26 \mathrm{c}$ & $49.33 \mathrm{a}$ & \\
Rib eye area (REA) $^{\text {(R) }}$ & $52.50 \mathrm{~b}$ & $42.64 \mathrm{c}$ & $57.76 \mathrm{a}$ & \\
INDEX & $16.08 \mathrm{~b}$ & $19.32 \mathrm{a}$ & $19.48 \mathrm{a}$ & \\
Shear force & $6.99 \mathrm{a}$ & $6.87 \mathrm{a}$ & $8.78 \mathrm{a}$ & \\
Holding water capacity & $76.1 \mathrm{a}$ & $78.4 \mathrm{a}$ & $77.6 \mathrm{a}$ & \\
Luminosity & $38.6 \mathrm{a}$ & $36.6 \mathrm{a}$ & $36.5 \mathrm{a}$ & \\
Red color intensity & $11.7 \mathrm{a}$ & $13.1 \mathrm{~b}$ & $12.9 \mathrm{~b}$ & \\
Yellow color intensity & $11.2 \mathrm{a}$ & $11.0 \mathrm{a}$ & $11.1 \mathrm{a}$ & \\
pH & $6.03 \mathrm{a}$ & $5.86 \mathrm{a}$ & $5.77 \mathrm{a}$ & \\
Cooking loss & $25.0 \mathrm{a}$ & $23.2 \mathrm{a}$ & $27.6 \mathrm{a}$ & \\
\hline & & & & \\
\hline
\end{tabular}

${ }^{1} 210$ days of age.

${ }^{2}$ Longissimus dorsi muscle area $\left(\mathrm{cm}^{2}\right)$

${ }^{3}(\mathrm{DRE} \times \mathrm{REA}) / \mathrm{CC}$. 
Table 4 - Maximum and minimum measures in growth, carcass, and meat traits of Nellore, Curraleiro Pé-Duro (CPD), and F1 crossbred progenies

\begin{tabular}{|c|c|c|c|c|c|c|}
\hline \multirow{2}{*}{ Trait/Breed } & \multicolumn{2}{|c|}{ Nellore } & \multicolumn{2}{|c|}{ CPD } & \multicolumn{2}{|c|}{$\mathrm{F}_{1}$ crossbred } \\
\hline & Maximum & Minimum & Maximum & Minimum & Maximum & Minimum \\
\hline Birth weight & 36.00 & 23.00 & 26.00 & 14.00 & 40.00 & 21.00 \\
\hline Weaning weight ${ }^{1}$ & 190.00 & 100.00 & 96.00 & 32.00 & 182.00 & 59.00 \\
\hline Yearling weight & 240.00 & 140.00 & 144.00 & 48.00 & 250.00 & 116.00 \\
\hline Weight at 18 months & 254.00 & 164.00 & 182.00 & 86.00 & 294.00 & 145.00 \\
\hline Weight at 24 months & 330.00 & 220.00 & 240.00 & 113.00 & 340.00 & 178.00 \\
\hline Slaughter weight & 354.00 & 294.00 & 298.00 & 186.00 & 342.00 & 236.00 \\
\hline Adjusted daily gain & 0.310 & 0.250 & 0.280 & 0.120 & 0.300 & 0.230 \\
\hline Hot carcass weight & 184.50 & 139.10 & 151.40 & 73.80 & 171.60 & 117.70 \\
\hline Chilled carcass weight (CC) & 180.90 & 136.20 & 148.40 & 72.00 & 168.10 & 115.00 \\
\hline Dressing percentage (DRE) & 51.10 & 45.00 & 49.80 & 38.70 & 51.60 & 45.10 \\
\hline Rib eye area $^{2}($ REA) & 63.50 & 46.00 & 58.00 & 37.00 & 70.50 & 52.00 \\
\hline INDEX $^{3}$ & 17.90 & 14.50 & 27.40 & 15.80 & 25.90 & 17.30 \\
\hline Shear force & 10.70 & 4.90 & 10.40 & 2.97 & 11.80 & 4.30 \\
\hline Holding water capacity & 79.30 & 70.50 & 81.20 & 74.20 & 82.10 & 73.80 \\
\hline Luminosity & 41.20 & 34.80 & 38.20 & 34.30 & 40.50 & 30.30 \\
\hline Red color intensity & 12.30 & 11.00 & 14.50 & 11.50 & 15.00 & 10.90 \\
\hline Yellow color intensity & 12.60 & 9.80 & 12.50 & 9.80 & 13.10 & 8.60 \\
\hline $\mathrm{pH}$ & 6.30 & 5.60 & 6.30 & 5.60 & 6.40 & 5.60 \\
\hline Cooking loss & 36.00 & 23.00 & 26.00 & 14.00 & 40.00 & 20.00 \\
\hline
\end{tabular}

${ }^{1} 210$ days of age.

${ }^{2}$ Longissimus dorsi muscle area $\left(\mathrm{cm}^{2}\right)$.

${ }^{3}(\mathrm{DRE} \times \mathrm{REA}) / \mathrm{CC}$.

Table 5 - Phenotypic correlations (\%) among body measurements and carcass traits in Nellore, Curraleiro Pé-Duro, and $\mathrm{F}_{1}$ crossbred progenies as one group

\begin{tabular}{lrccccccc}
\hline Trait & BW & $210 \mathrm{~W}$ & $365 \mathrm{~W}$ & $18 \mathrm{~W}$ & $24 \mathrm{~W}$ & SW & HC & DRE \\
\hline $210 \mathrm{~W}$ & 35 & & & & & & & \\
$365 \mathrm{~W}$ & 47 & 91 & & & & & & \\
$18 \mathrm{~W}$ & 53 & 92 & & & & & & \\
$24 \mathrm{~W}$ & 53 & 80 & 83 & 83 & & & & \\
SW & 56 & 80 & 87 & 88 & 87 & & & \\
HC & 53 & 76 & 84 & 84 & 85 & 98 & & \\
DRE & 34 & 52 & 60 & 58 & 66 & 76 & 87 & \\
REA & 24 & 38 & 47 & 44 & 44 & 50 & 56 & 59 \\
\hline
\end{tabular}

BW - weight at birth; $210 \mathrm{~W}$ - weight at weaning at 210 days of age; $365 \mathrm{~W}$ - weight at yearling at 365 days of age; $18 \mathrm{~W}$ - weight at 18 months of age; $24 \mathrm{~W}$ - weight at 24 months of age; SW - weight at 28 months of age in the day of slaughter; HC - hot carcass; DRE - dressing percentage; REA - Longissimus dorsi muscle area in $\mathrm{cm}^{2}$.

\section{Discussion}

No significant difference among weights of males and females were found in this experiment, which could be explained by the better pastures offered to females, since they would be directed to reproduction and maintained in farm herds, while males would be sent to slaughter.

In addition, a significant effect was observed among breeds, probably due to well-known factors such as the differentiated selection of animals in their origins, India and Portugal. Nellore cattle were chosen by selecting large specimens with good carcass by some Brazilian farmers and after arrival, they have undergone a breeding process until present day. According to the Associação dos Criadores de Nelore do Brasil (ACNB, 2017), animals introduced in Brazil were selected by local breeders and constituted types with characteristics close to the existing in India and considered pure lineages, which supposedly gave rise to the Brazilian Zebu.

On the other hand, animals that gave rise to Curraleiro Pé-Duro breed differ widely from each other, both in genetic structure and some influences from other breeds (Martinez et al., 2012). Local breeds may compromise centuries of selective adaptation to a wide range of environmental conditions. It is noteworthy that CPD cattle has gone through constant challenge of natural selection in often hostile environments, with roughage and far waterholes, where large animals were naturally disadvantaged. These facts have led to a wide range of results in all traits among and within the evaluated breeds.

Due to huge mature weight difference between parental breeds (Nellore and CPD), Nellore offsprings were significantly heavier in all weight measurements performed, from birth to slaughter, when compared with $\mathrm{F}_{1}$ and $\mathrm{CPD}$ progenies (Figure 1). In contrast, Vaz and Restle (2001), studying breed and heterosis effects on carcass traits of steers from the first crossbreeding generation between Charolais and Nellore, showed that $F_{1}$ (crossbred steers) were superior to purebreds in slaughter weight, carcass weight, conformation, carcass length, cushion thickness, 
arm perimeter, sidecut percentage, fat thickness, and Longissimus muscle area. The difference in results about $F_{1}$ weights related by these authors and our findings can be easily explained by the difference in size of parental breeds involved in both experiments.

A construction of an INDEX is justified because we do not want to simply compare weight gains in different breeds, but assess the amount of meat produced per $100 \mathrm{~kg}$ carcass produced in relation to the animal size in natural environments in hot tropics. This is a real challenge in modern times and may become worse in near future due to climate change. Therefore, as the results also showed, despite the greater weight gain of the Nellore group, they did not produce more meat as $\mathrm{F}_{1}$ group did. Even with lower weight measurements, $\mathrm{F}_{1}$ showed greater Longissimus dorsi muscle area (REA) and, therefore, more meat produced per $100 \mathrm{~kg}$ of carcass (INDEX), indicating also an improved beef quality in the same circumstances with the same effort. Although no significant difference was observed related to tenderness in meat produced among studied groups, CPD showed a tendency to be softer, with one animal that presented 2.97 of shear force, which can be considered an extremely tender meat.

In this work, the progeny between Nellore and Curraleiro Pé-Duro presented lower birth weight than Nellore group, a fact that would avoid problems at birth favoring cow and calf survival. Similar evidence was reported by Chase et al. (2000) when assessing the progeny growth rates of Angus cows crossbred with tropically adapted bulls, such as Brahman, Senepol, and Tuli. They reported that Brahman and Angus produced progeny with higher birth and weaning weight than Senepol or Tuli, but showed higher calving difficulty and lower survival rate at birth during the study period.

Euclides Filho et al. (2002), studying the effect of different genetic groups on performance, presented the hypothesis that larger animals have higher nutrient

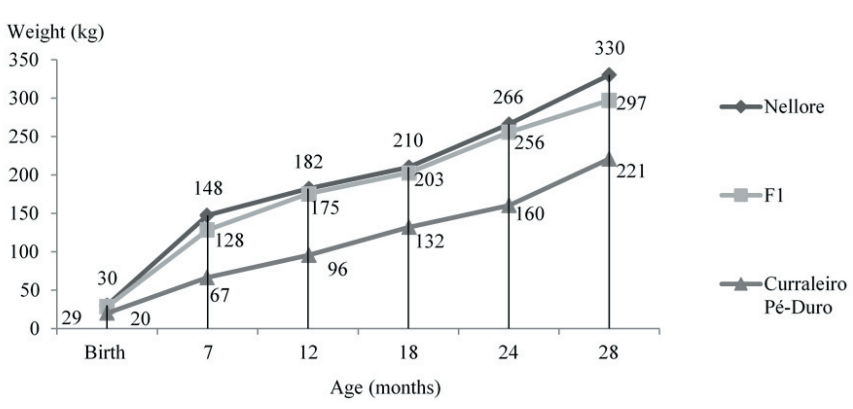

Figure 1 - Growth performance of Nellore, $\mathrm{F}_{1}$, and Curraleiro Pé-Duro progenies at different ages. requirements than smaller animals for their maintenance and, therefore, can exhibit better weight gains, while in smaller animals, the available nutrients from natural environment could be directed to meat production. Such hypothesis, as well as heterosis, also could explain such a similar carcass yield, even at a lower body weight gain, as observed in the $\mathrm{F}_{1}$ group in this study when compared with Nellore group (REA and INDEX) (Table 3).

The levels of heterosis found in quantitative traits (Table 3) could be considered moderate to high and this should be considered when explaining weight gain in $\mathrm{F}_{1}$ group when compared with pure CPD. Coleman et al. (2012) also reported such levels of heterosis in crossbred products of Romosinuano (B. taurus, tropical), Brahman (B. indicus, tropical), and Angus (B. taurus, temperate) beef cattle. Sollecito et al. (2016), working with heifers from different genetic groups, Guzera, $1 / 2$ Guzera $\times 1 / 2$ Nellore, and $1 / 2$ Red Angus $\times 1 / 2$ Nellore, also stated that crosses between $B$. taurus $\times B$. indicus leads to higher reproductive and productive performances than pure Guzera or $F_{1}$ (Guzera $\times$ Nellore).

In general, $F_{1}$ from unrelated breeds exhibit higher levels of heterosis, due to more heterozygosis locus, than do crosses of more genetically similar breeds from a common origin. Even though NEL and CPD cattle are both well adapted to hot tropical environments, their body weights and sizes are very distant and show somewhat great differences in performance that can explain, in part, such high levels of heterosis in $\mathrm{F}_{1}$ products. Furthermore, some good heterozygote complementarity adding their inherent aggregated relative success in the ability to manage the poor environment offers may have its part.

Phenotypic correlations (\%) among body measurements and carcass traits were moderate to high, which indicate that selection at weaning or yearling could improve dressing percentage, REA, and INDEX in carcass. The results found in this evaluation is in accordance with those compiled by Bonilla et al. (2007), when evaluating effects of 20 years of selection for post-weaning weight on carcass traits and meat quality in experimental herds of unselected Nellore and selected Nellore, Caracu, Guzera, and Gyr breeds from a genetic selection program in Sertãozinho, SP, Brazil.

A great amplitude between minimum and maximum measurements in the analyzed genotypes in this research was observed. There was a great variability in and among breeds and an extent field for genetic improvement to identify and select top animals to improve weight, ADG, REA, dressing percentage, and tenderness performance (Table 4). 
Mature weight improvement, especially in cows, might not be an objective in places where forage resources are characterized by seasonal variability in quality and quantity. The smaller size of $\mathrm{F}_{1}$ produced would benefit maternal lines for production of $\mathrm{F}_{2}$ with higher stocking rate on pastures and increased production of calves in the same area than using pure strains of Nellore. It would also increase beef production per hectare using this tropically adapted Taurine (Curraleiro Pé-Duro) in crosses with Nellore in Piauí and in other similar places.

As highlighted by Blackburn and Gollin (2009) about the successful introduction of new breeds into the USA based on production traits, we agree that the same should be done in the Brazilian beef chain and the interest and acceptance by private sector in local breeds might happen. We could also imply, based on these research results, that market interest could also be achieved by producing higher proportion of fine meats with added value in $F_{1}$ genetic group, as indicated by INDEX, at a lower cost.

Beef consumption worldwide is expected to continue rising mainly in emerging countries. Production systems of pasture-based fastening in tropical regions by using tropically adapted germplasm may be the sustainable path, but only the well-evaluated local breeds will be used by agribusiness to replace or mate with commercial breeds. Meat production in a low-input system in a hot semiarid environment is a challenge and breed adaptation, including mature size, is a crucial prerequisite. By using CPD cattle in crossbreeding, it is possible to reach several targets with better prices, improve meat quality, take advantage of natural environments, and remove the risk of extinction of this singular cattle breed. This may be a safe way to solve problems stated by Euclides et al. (2001) about the sustainability of beef production in Brazil. In other words, to be politically correct, we do not need to enhance animal nutrition; we must better use our animal genetic resources to use more efficiently our rangelands without degrading Cerrado, Caatinga, and Amazon rainforest Biomes, especially in a global warming scenario.

\section{Conclusions}

The great amplitude between minimum and maximum results in growth performance, carcass traits, and meat quality are an indicative of the possible use of genetic improvement tools in Curraleiro Pé-Duro cattle.

Curraleiro Pé-Duro and $\mathrm{F}_{1}$ crossbred produce more meat per $100 \mathrm{~kg}$ of carcass than Nelore in natural pasture of Piauí State.

\section{Acknowledgments}

Authors acknowledge the financial support from Empresa Brasileira de Pesquisa Agropecuária (EMBRAPA).

\section{References}

ACNB - Associação dos Criadores de Nelore do Brasil. 2017. A raça - A origem. Available at: $<$ http://www.nelore.org.br/raca $>$. Accessed on: May. 22, 2017.

Athanassof, N. 1946. Tipos e raças de gado bovino. p.215-225. In: Manual do criador de bovinos. Athanassof, N. Melhoramentos, São Paulo.

Blackburn, H. and Gollin, D. 2009. Animal genetic resource trade flows: the utilization of newly imported breeds and the gene flow of imported animals in the United States of America. Livestock Science 120:240-247.

Bonilha, S. F. M.; Tedeschi, L. O.; Packer, I. U.; Razook, A. G.; Alleoni, G. F.; Nardon, R. F. and Resende, F. D. 2007. Evaluation of carcass characteristics of Bos indicus and tropically adapted B. taurus breeds selected for postweaning weight. Journal of Animal Science 86:1770-1780.

Britto, C. M. C. and Mello, M. L. S. 1999. Morphological dimorphism in the Y chromosome of "Pé-duro" cattle in the Brazilian state of Piauí. Genetics and Molecular Biology 22:369-373.

Cardoso, C. C.; Lima, F. G.; Fioravanti, M. C. S.; Egito, A. A.; Silva, F. C. P.; Tanure, C. B.; Peripolli, V. and McManus, C. 2016. Heat tolerance in Curraleiro Pe-Duro, Pantaneiro and Nelore cattle using thermographic images. Animals 6:2-11.

Chase Jr, C. C.; Hammond, A. C. and Olson, T. A. 2000. Effect of tropically adapted sires on preweaning growth of F1 Angus calves and reproductive performance of their Angus dams. Journal of Animal Science 78:1111-1116.

Coleman, S. W.; Chase, C. C.; Phillips, W. A.; Riley, D. G. and Olson, T. A. 2012. Evaluation of tropically adapted straightbred and crossbred cattle: postweaning gain and feed efficiency when finished in a temperate climate. Journal of Animal Science 90:1955-1965.

Euclides, V. P. B.; Euclides Filho, K.; Costa, F. P. and Figueiredo, G. R. 2001. Desempenho de novilhos F1s Angus-Nellore em pastagens de Brachiaria decumbens submetidos a diferentes regimes alimentares. Revista Brasileira de Zootecnia 30:470-481.

Euclides Filho, K.; Figueredo, G. R. and Euclides, V. P. B. 2002. Eficiência bionutricional de animais da raça Nellore e seus mestiços com Caracu, Angus e Simental. Revista Brasileira de Zootecnia 31:331-334.

Hammack, S. P. 2012. Texas adapted genetic strategies for beef cattle $\mathrm{V}$ : Type and breed characteristics and uses. Agrilife Extension. Texas A\&M System: E/190 - 3/09.

IBGE - Instituto Brasileiro de Geografia e Estatística. 2014. Rebanho bovino brasileiro cresce e chega a 12,3 milhões de cabeças. Available at: <http://www.brasil.gov.br/economia-e-emprego/2015/ 10/rebanho-bovino-brasileiro-cresce-e-chega-a-212-3-milhoes-decabecas-de-gado>. Accessed on: Jan. 13, 2016.

Martinez, A. M.; Gama, L. T.; Cañón, J.; Ginja, C.; Delgado, J. V.; Dunner, S.; Landi, V.; Martín-Burriel, I.; Penedo, M. C.; Rodellar, C.; Vega-Pla, J. L.; Acosta, A.; Alvarez, L. A.; Camacho, E.; Cortés, O.; Marques, J. R.; Martínez, R.; Martínez, R. D.; Melucci, L.; MartínezVelázquez, G.; Muñoz, J. E.; Postiglioni, A.; Quiroz, J.; Sponenberg, P.; Uffo, O.; Villalobos, A.; Zambrano, D. and Zaragoza, P. 2012. 
Genetic footprints of Iberian cattle in America 500 years after the arrival of Columbus. PLoS ONE 7:e49066. doi: 10.1371/journal. pone.0049066

Moreira, R. P.; Mercadante, M. E. Z.; Pedrosa, V. B. and Cyrillo, J. N. S. G. 2016. Growth curves on females of the Caracu breed. Semina: Ciências Agrárias 37:2749-2758.

Sollecito, N. V.; Andrade, V. J.; Barbosa, F. A.; Lobo, C. F.; Azevedo, H. O. and Guimaraes, P. H. S. 2016. Taxa de fertilidade de novilhas de diferentes grupos genéticos com primeiro serviço aos 14 meses de idade. Arquivo Brasileiro de Medicina Veterinária e Zootecnia 68:361-368

Vaz, F. N. and Restle, J. 2001. Efeito de raça e heterose para características de carcaça de novilhos da primeira geração de cruzamento entre Charolês e Nellore. Revista Brasileira de Zootecnia 30:409-416.

Wheeler, T. L.; Shackekford, S. D. and Koohmaraie, M. 1998. Cooking and palatability traits of beef longissimus steaks cooked with a belt grill or an open hearth electric broiler. Journal of Animal Science 76:2805-2810. 